\title{
Exploring the Practice of Teacher-Student Classroom Interaction in EFL to Develop the Learners' Speaking Skills in Tullu Sangota Primary School Grade Eight Students in Focus
} Habtamu Walga Adaba*

Ambo University, College of Social Sciences and Humanities, Ethiopia

\begin{abstract}
In the process of Second Language Acquisition (SLA), classroom interaction takes an important place. Teachers need to apply appropriate classroom interaction to facilitate language learning in reality since interaction is in the heart of communication in an era of communicative language teaching. Therefore, the purpose of this study was conducted to assess teachers' application of classroom interaction on developing the students speaking skills in Tullu Sangota Primary school grade 8. Specifically, the study was intended to assess whether the teacher uses a variety of classroom interactions. In order to achieve the objectives of the study, a descriptive survey method was used and the data were gathered through questionnaires, classroom observation, and interview. Both open-ended and close-ended questionnaires were distributed to the sample students and semi-structured interview questions were employed with sample English teachers. Observation was also held based on checklist and chosen criteria in accordance with the objective of the study. To assess teachers' application of classroom interaction on developing students speaking skills, 100 sample students from grade 8 and 4 English teachers were taken for the study from Tullu Sangota Primary Schools. The collected data was analyzed using percentage and frequency. Based on the information gathered through the above instruments and its results and discussion, the findings of the study revealed that teachers rarely played their role to develop the students speaking skills in the classroom due to lack of awareness, having negative attitude toward classroom interaction, lack of simple materials to practice classroom interaction, low participation of the students in the class, and lack of access of teaching aids inhibits the teachers to apply classroom interaction. Based on the implications of the findings, recommendation was made to language teachers, students, Tullu Sangota Primary, Ministry of Education and concerned bodies. Finally, on the bases of the findings, it was recommended that in order to improve the students speaking skill: The students have to practice in classroom interaction to develop their speaking skill in the target language by actively participating in the classroom speaking. In addition, teachers also ought to play a prominent role to improve the students speaking skill by using an appropriate classroom interaction which give equal chance for the students to participate actively in the classroom interaction.
\end{abstract}

Keywords: Interaction; Classroom interaction; Speaking; Language input; Language output; CLT

\section{Introduction}

In the field of second language acquisition, classroom interaction received rigorous attention from interactionists researchers [1]. Classroom interaction takes an important place in the process of language teaching and learning through giving learners opportunities to receive the input that is provided by the teacher, learners or material which must be understood by the learners in order to make them involved in the classroom task by providing the output [2]. Interaction in English classroom is in the heart of communication in an era of communicative language teaching [3]. Therefore, teachers need to be aware of to what extent their classroom practices facilitate language learning in reality. The communicative language teaching theory reveals that communication and interaction are the purpose of language learning [4]. Previous studies on communicative language teaching Nunan show that interaction facilitates the learning of language functions as well as of target language forms. Crystal further explained this as the need for English speaking mastery has increased due to the status of English as a global language which is recognized in every country. Moreover, Crystal explained that English has become the language of communication, business, education, and opportunity in general argued that the function of mastering speaking English as the main gate to succeed in school and out of the school since it is used as the working language in international organizations and companies [59]. Brown said that in countries where English is used as foreign language, the students need to practice English in language classroom. To get experience in English speaking, they need to interact with the teachers, themselves and with materials regularly using the target language because interaction is the heart of communication. Unfortunately, the interaction in the language classroom seems to the teachers in the classroom all the time, especially in the EFL (English as a Foreign Language) classroom. The goal of teaching process then could not be achieved if the teacher of EFL ignores it. This is why Raiver said that interaction plays significant roles in the language classroom since it can increase students' language store, strengthen the social relationship, develop communication skill and build up confidence [10-13]. For the interaction in the language classroom has advantages to the students' speaking performance, therefore, the study about

*Corresponding author: Habtamu Walga Adaba, Professor, Ambo University, College of Social Sciences and Humanities, Ethiopia, Tel+251 11236 2006; E-mail: duressaw@gmail.com

Received August 15, 2017; Accepted August 19, 2017; Published August 25, 2017

Citation: Adaba HW (2017) Exploring the Practice of Teacher-Student Classroom Interaction in EFL to Develop the Learners' Speaking Skills in Tullu Sangota Primary School Grade Eight Students in Focus. Arts Social Sci J 8: 295. doi: 10.4172/2151-6200.1000295

Copyright: @ 2017 Adaba HW. This is an open-access article distributed under the terms of the Creative Commons Attribution License, which permits unrestricted use, distribution, and reproduction in any medium, provided the original author and source are credited. 
teachers' use of appropriate classroom interaction is considerably important. The predominance of social constructivism and sociocultural approaches to language learning and teaching has placed classroom interaction under new hot issue in the classroom where English Language is being used as the medium of instruction in high schools [14-19]. Hence, learners are expected to have adequate proficiency in using the language. In the practice of our English language teaching and learning, lack of appropriate classroom interaction is a common thing. However, the learners' skills in using the language highly determine their academic success in the school or after school [20]. Therefore, teachers should use appropriate classroom interaction during speaking lesson in order to develop the students' English language skills in general and speaking skills in particular through classroom interaction. Interaction in classroom which aims at teaching the target language come from different interaction types like teacher speaking to the individual, members of a group and the whole class, a student speak to the teacher, to another student, to group members, and to the whole class. Based on the above types of interaction, the present study is intended to assess the teachers-students and students-students classroom interaction in the EFL speaking class. The issue this paper is concerned with an assessment of teachers' application of classroom interaction to improve the students' speaking skills. Some local research works have also been carried out in relation to this area. However, their findings are relevant and provide us useful data on the students' problem of speaking in general. For example, Hailom focused on the problems that exist in teaching English as foreign language in applying the principles of CLT in the actual classroom situation in Ethiopia. The problem observed in teaching was that many teachers complain that Ethiopian students are incapable of communicating in English in EFL classes [21]. Other local researches conducted were investigated on their findings revealed the factors that affecting the students' speaking skills in general [22-25]. Their study result also show us that problems related to the syllabus seems to be partially resolved, but other problems, especially the teachers' traditional teaching method has continued to hinder the implementation of appropriate classroom interaction in Ethiopia. In addition to this, a thesis done at Ambo University tried to mention some high school students' problems of speaking in the classroom is anxiety and shyness revealed that students have difficulties in using the language and interacting productively in the classroom [26]. These could show that there is no relaxed environment to interact. Therefore, appropriate application of classroom interaction is still under question mark. The researcher of this study believes that one ways of increasing the students' participation in the classroom is by applying appropriate classroom interaction can increase the students' active participation. From his teaching experiences, the researcher of this study observed that the Ethiopian new curriculum is prepared in such a way that let the students to interact with each other and with the teachers. However, the most important question is that "How much what is designed is done in the classroom to develop speaking skills in general and at the selected school in particular?" In relation to this idea, Richards and Rodgers mention that reading and writing are the essential skills to be focused on however, little or no attention is paid to the skill of speaking and listening in classroom. Although the current language teaching approach in Ethiopia is CLT, many high schools teachers often face problems in making good classroom interaction in English classroom, and sometimes the students do not have the chance to express their ideas or even interact with each other. Long commented that "...the teacher is responsible for providing opportunities for interaction in which learners control the topics and discourse." From the researcher's teaching observation, most teachers of Meti High School teachers have experienced classes in which students' interaction has been more limited to teachers' talk in the classroom. It seems that they neglected appropriate application of classroom interaction and students have little chance to practice the target English language in class. This is why most of the Meti grade nine students hardly ever communicate in English like participating in the classroom interaction. The researcher personal experience also witness that some students try to respond with nods and shakes of the head, and some of the students always keep their heads down and remain silent when asked questions or assigned to group work. However, Long said that if a student fails to communicate with the target language, the aim of language teaching may not be said to achieve its goal for language learning. The other reason why the researcher initiated to study on the teachers' use of classroom interaction is that there are no classroom studies that have been carried out on classroom interactions in Meti Secondary School. While most teachers admit to be following a communicative approach, in practice they are following more traditional approaches. Therefore, this paper focuses on an assessment of teachers' application of classroom interaction in English classroom interaction at grade nine level at Meti Secondary School because this level is critical time to care of their future language abilities and learning in general.

\section{Objectives}

\section{General objective}

The main objective of this study was to assess the teachers' application of classroom interaction to develop the students' speaking skills.

\section{Specific objectives}

The specific objectives of this study were:

- To identify how often the teachers apply classroom interaction to develop the learners' speaking skills.

- To investigate teachers' opinion about applying classroom interaction in developing the students' speaking abilities.

- To find out whether the learners give an important value to classroom interactions that happens inside the classroom in activating their speaking skill through participating with their classmates or teachers.

- To find out how often teachers and learners practice the communicative language teaching and classroom interaction in their classes.

\section{Review of Related Literature}

\section{Definition of classroom interaction}

Classroom Interaction (CLI) is a practice that enhances the development of language skills. This device helps the learners to be competent enough to think critically and share their views among their peers. Interaction in the classroom is an essential part of teaching learning process. Interaction or human interaction has been defined as a process whereby two or more people engaged in reciprocal actions. This action may be verbal or nonverbal. Defined interaction as the students' participation requires a high degree of interpersonal communication skills. It refers to the exchange of information between the teacher and the students or among the students. The Cambridge Advanced Learners' Dictionary defines interaction as when two or more people or things communicate with or react to each other. In addition, Brown describes the term of interaction "as the heart communication; 
it is what communication is all about." Interaction occurs as long as people are communicating each other and giving action and receiving the reaction in one another anywhere and anytime, including in the classroom setting [27].

\section{Importance of classroom interaction}

Classroom interaction used as building knowledge and improving language skills. Byreducing the amount of teachers talk in classroom and by increasing the learners' talk time, it keeps the learners active in the classroom. The importance of interaction has a significant role both in the classroom and out of classroom. Therefore, teachers and students should consider it as an essential part in learning and teaching language skills, especially in speaking class. They also added that classroom interaction helps the teachers to manage who should talk, to whom, on what topic, in what language. According to the classroom interaction which is a productive teaching technique manages the classroom language learning. "Interaction is face-to-face communication with Particular prosody, facial expression, silence, and rhythmical patterns of behavior between the participants. Interaction also provides opportunities for production and receiving feedback. Interaction in classroom is based on the input provided by both teacher and students. The interaction can be between teacher and students and also between student and student. Both of these kinds of interaction need to be enhanced in the classroom environment. Nugroho stated that classroom interaction has a significant role. Experiencing something by oneself will help learning it better and in the classroom environment it has been gained by engaging in classroom activities. Interaction between students and teacher influences the learning success. Learning opportunities are more for those who are active in conversation through taking turns than those who are passive. Interaction is viewed as significant by Chaudron cited in Nurmasitah because analyzing target language structures and getting the meaning of classroom events is done via interaction. It is through interaction that learners gain opportunities to insert the derived structures of classroom events into their own speech (the scaffolding principles). The communication constructed between the teacher and learners determine how much classroom events are meaningful for the learners. Classroom interaction does not only promote English language development but it also fosters the development of social skills (e.g. politeness, respect for others) that people need to operate successfully in any culture [28]. Classroom interaction also develops the learners' socialization. Related to the concept of collaboration is that of socialization. Interaction does not only promote language development but it also fosters the development of social skills (e.g. politeness, respect for others) that people need to operate successfully in any culture.

\section{Interaction as a type of CLT frameworks}

CLT relies mainly on the value of interaction; person to person encounter. Teachers and learners then should learn and use it in classroom. Researches about classroom communication that involves interaction showed the importance of interactions as building knowledge and improving skills. It is important to keep learners active in the classroom, which means reducing the amount of teachers talk in classroom and increasing the learners' talk time. CLT relies mainly on the value of interaction; person to person encounter. Teachers and learners then should learn and use it in classroom.

\section{Components of classroom interaction}

Classroom interaction involves two main aspects. These are negotiation of meaning and feedback. We cannot speak of a successful learning through interaction, if these elements are not available in the classroom. This is why Ellis and Foto explained "Interaction contributes to acquisition through the provision of negative evidence and through opportunities for modified output." This means the learners can receive feedback from their interlocutors. Negotiation of meaning [29-32].

\section{Types of classroom interaction}

Classroom interaction encompasses all types of interaction that goes on in a classroom. There are several different ways to categorize classroom interaction, but all of the types of interaction are important to engage learning and to create well rounded young people inside and outside the classroom If the teachers dominate the activities in the classroom, it is traditional approach. Therefore, classroom interaction shouldn't be one-way, but two-way, three-way or four-way Rivers Understanding the types of interaction help one to understand the role of classroom interaction to improve the learners' speaking skills. See the following types of interaction:

Teacher-learner interaction: The role of teacher is should know that the learners need to do most of the talk to activate their speaking, since this skill requires practice and experience to be developed. Because Classroom interaction then involves the verbal exchanges between learners and teachers; If teachers are advised to reduce their time of talking in the classroom interaction, then it does not mean that they have no role to play. Involving all of the learners in the interactive activities is their main job; they must apply some of the teaching strategies to get all of the students to talk.

Teachers should focus on three things when they talk with their students. Firstly, they must pay attention to the kind of the language the students are able to understand, i.e. teachers should provide an output that is comprehensible for the level of all the students. Secondly, the teachers must think about what they will say to their students, hence the teacher speech is as a resource for learners. Finally, teachers also have to identify the ways in which they will speak such as the voice, tone and intonation.

Learner-learner interaction: According to Johnson supports that if learner-learner interaction is well structured and managed, then it can be an important factor of: cognitive development, educational achievement of students and emerging social competencies and develop the learners' capacities through collaborative. Materiallearners interaction which can be text-based materials, task-based materials and realia

\section{Types of speaking}

There are 5 kinds of speaking.

1. Imitative speaking: This is ability to repeat back others' speech.

2. Intensive speaking: This type of speaking is like reading aloud, completing dialogue.

3. Responsive speaking: Responsive speaking is engaging in classroom interaction like in conversation or dialogue. This kind of speaking helps one to exchange specific information.

4. Interactive speaking: This is involves interpersonal and intrapersonal communication. Interactive speaking is more length and complex than responsive speaking. This kind of speaking helps one to develop social relationship. For example: interviewing, role play, and discussion.

5. Extensive speaking: Extensive speaking is a monologue like telling 
story, delivering speech, and oral presentation. This kind of speaking uses formal language $(\mathrm{p}, 142)$. The key to a successful speaking lesson is a successful speaking activity. Presenting a good speaking lesson is depending on the interaction between teachers and students, students and students, between students and materials. Fluency and accuracy are main characteristics approach in the communicative approach of language teaching $[33,34]$.

\section{Language input and language output}

The Input Hypothesis claims that language input (listening comprehension and reading) is important in the language program and that fluency in speaking or writing in a second language will naturally happen after learners have built up sufficient competence through comprehending input noted that interaction facilitates comprehension and acquisition of semantically contingent speech and negotiation for meaning. Long stresses the importance of the interactional modifications that occur in negotiating meaning. In other words, interactive input is more important than non-interactive input. Teachers" input in the interaction process also influences the learning process in many important ways, particularly learners' attitudes towards the instructor, the peers and the subject matter. Johnson and Johnson argue that clarity of instructions is instrumental in both the interaction process and the learning outcomes [34-36].

\section{Grammar translation methods}

According to Brown this method is focused on isolated sentence by neglecting real life communication.

Natural methods: This method of teaching speaking skill is focused on the spoken language. It focuses on teacher-student interaction. The students respond to the teachers' activities through action which $s$ called Total Physical Response

Situational and audio-lingual methods: Following the spoken form gain a more important status in the language teaching through the first half of the twentieth century; this means that the speech here is considered as the primary medium of instruction

Communicative approach: In the field of (ELT), this method has a wide and deep influence speaking was given more importance in this approach because learners are exposed to interact with other classmates, teachers or materials. Develop the learners' communicative competence is regarded as the central part of the learning process. With the importance of English on today's world, the communicative approach or (CLT) is considered as the best approach of teaching in the classroom and learning language on general. Therefore, a deep understanding of CLT implication for classroom practice is very important for both learners and teachers.

Communicative competence: The communicative approach is mainly based on the theory of communicative competence that includes grammatical, sociolinguistic, discourse and strategic competence. According to Hedge who has been explaining these as: Sociolinguistic competence or pragmatic competence refers to the social rules of language use which includes a better understanding of the social context where communication takes place like the shared knowledge of the participants; It is also called the illocutionary competence. Discourse competence deals with the ability to understand individual messages and to recognize all the discourse features. Strategic competence consists of the strategies involved for a successful communication; such strategies take place when learners cannot express what they want to say because they lack the resources to do so. In the communicative approach, most researchers agree on the need for the communicative competence to support learning and make the classroom interaction successful. Johnson claims that "classroom Communicative competence is essential in order for the second language students to participate in and learn from their classroom experience." The statements quoted above make it clear that no single approach or method is appropriate for all learning styles. A good lesson will, therefore, be one in which the teachers use a smorgasbord of activities taken from a variety of sources. By varying our techniques, we will give students of all styles the chance to shine some of the time. In general, the students learn by participating and communicating in classroom. Therefore, the students' talk time (STT) should be greater than teachers' talk time (TTT). This means the teachers are facilitators and guide [37].

Teachers' and students' roles in the CLT classroom: Nowadays Communicative Language Teaching (CLT) has become a wellrecognized approach in this profession.

Roles and responsibilities of teachers during classroom interaction: Scrivener suggested that, teachers most important job has to be creating condition in which learning can take place maximizing students' interaction in class.

Let us see some of the teachers' roles and responsibilities:

1. Controller: Harmer said that within a classroom interaction, the teacher is the responsible for the teaching and learning processes. Here teacher job here is to transmit knowledge from himself to his students.

2. Assessor: the other teachers' responsibility is to show the learners that their accuracy is being developed by giving correction or by praising them. The teacher should tell strengths and weaknesses of the students so that they have a clear idea about their levels and what they need to concentrate on.

3. Corrector: This is when and where to correct students' production. The teacher should careful when correcting pronunciation mistakes or errors the learners commit during classroom interaction.

4. Organizer: according to Harmer teachers should set up different things like organizing pair, group work, giving learners instructions and finally stopping everything when the time is over.

5. Prompter: This is the teachers' role to encourage the learners to think creatively so that to be independent from the teacher.

6. Resource: The teachers should be used as a resource in classroom or out of the classroom. The job of the teacher here is to answer students' questions.

7. Observer: The teacher should observe the students' classroom interaction. Harmer points out that, the teacher should attract the students" attention so that they can interact naturally and spontaneously.

Designing pairs and groups: Harmer asserts that pair works increases the amount of each student's speaking time. Group work is like pair work because it increases the amount of talking time for individual students, but unlike pair work because more students will contribute in the interaction; they will have different ideas and varied opinions. Harmer sets up a set of principles that teachers can be based on when creating pairs and groups because it is very essential in varying the interactive learning.

1. Friendship: When grouping learners, the teachers should 
consider putting friends with friends. The learners would choose and go towards other students they like, admire or want to be liked by.

2. Streaming: The teachers can arrange students into pairs or groups according to their abilities. Participation is one basis that the teachers might focus on during streaming. The other basis is based their ability levels i.e. high level, medium level and low level ability. The teachers need to mix these students so that they can help each other.

3. Chance: This is the easiest way of creating groups or pairs because it does not require pre-planning from the teachers he teachers can group the learners by chance without any reason of friendship, ability or level of participation, and. One way of grouping the learners under this basis of chance is sitting; the learners who sit next or near each other will interact together.

4. Changing groups: The teachers can change the group while the interactive activity continues. For example one member from other groups can interact with the actual group and share information with them, and then he may come back to his original group. Groupbased learning is used on a large scale in many forms of teaching. Firstly, it changes the interactional dynamics in the classroom and increases students' talking time. There is also a greater opportunity of different opinions and varied involvements than in pair work, and it encourages learner's autonomy by allowing students to make their own choices within the group, without being told what to do. group work is likely to be an interaction pattern which is typical of full of noise. Littlewood there are two types of communicative activities: functional communication and social interaction activities. There are a variety of communicative activities (e.g. games, role plays, simulations, and problem-solving tasks), which offer learners an opportunity to practice their communication skills meaningfully in different contexts and by taking on different roles. In the process of utilizing these kinds of performance activities, learners avoid using their native language and teachers occasionally, if ever, correct students' mistakes.

\section{Communication Games}

Communication games are another type of speaking activities proposed by Harmer the word game suggests an element of fun during a lesson (indeed, learners draw pictures, solve puzzles, etc.), but of course games are designed to provoke communication between students and often depend on an information gap. According to Bygate such activities include first, 'Describe and Draw' in which one student describes a given picture and the other one draws it. Second, 'Describe and arrange'; one student describes a particular structure using oral language and the other reconstructs it without seeing the original one. Third, 'Find the difference', two students have two similar pictures but with some differences, they must extract these differences through describing their pictures, i.e. without seeing each others.

\section{a) Drama, simulations and role-plays}

These three types of oral activities are very important - according to Bygate - they are not performed for audiences, the participants work together within an imaginary setting.

\section{b) Discussion activities}

In discussions activities, learners are presented with problems and have to express their own opinions about it. Students also retain their personalities and views and their task is to come to an agreement considering an issue introduced by the teacher [38].

\section{c) Presentations and talks}

The best way to make students gain their self-confidence is through making them present oral works in front of their classmates [39-42].

\section{d) Identifying Pictures}

Learner A has a set of five or six pictures which are very similar in content, but contain a number of distinguishing features. Learner $B$ has a duplicate of just one of these pictures. Learner A must find out which of the pictures learner B is holding, by asking him questions about it.

\section{e) Discovering Identical Pairs}

A similar set of, say, four pictures is now distributed among four learners, who thus have one picture each. A fifth learner in the group holds a duplicate of one of the pictures. He must question the others in order to discover which learner has the picture identical to his own.

\section{f) Discovering Sequences or Location}

Learner A has a set of, say, six pictures or patterns. These are arranged in to a sequence from one to six (either in advance or by A himself). Learner B has the set of pictures, but these are not in sequence. Learner B must discover the sequence of A"s picture and arrange his own in the same way.

\section{g) Discovering Missing Features}

Learner A has a picture, for example, a street or a country scene. Learner B has the same picture, except that various items have bee deleted from it. Learner A (i.e. the partner with a complete picture) must take initiative in asking questions. He must find out which details have not been reproduced in B" version of the picture.

\section{h) Discovering Secretes}

One learner has a piece of "secret" information, which the other in his class or group must discover by asking appropriate questions. The questions must be restricted to a certain kind, such as Yes/No questions, in order to prevent the discoverer from simply asking directly for a piece of information.

\section{i) Discovering Differences}

Learner A and learner B each have a picture (or a map, pattern etc.). The pictures are identical except for a number of details. For example, two street scenes may be identical except that one of the people is in a different position, one car is in a different color and there is a different number of clouds in the sky. The learners must discuss the picture in order to discover what the differences are.

\section{j) Following direction}

Learner $\mathrm{A}$ and learner $\mathrm{b}$ have identical maps. Only A knows the exact location of some building or other feature (e.g. a "hidden treasure"). He must direct B to the correct spot.

\section{k) Reconstructing Story- sequence}

A picture-strip story (without dialogue) is cut up into its separate pictures. One picture is handed to each member of a group. Without seeing each other's pictures, the learners in the group must decide on the original sequence and reconstruct the story. Richards (2006) mentions and discusses some important CLT classroom activities and are presented below.

\section{1) Task Completion activities}

Puzzles, games, map-reading and other kinds of classroom tasks 
in which the focus was on using one's language resources to complete tasks.

\section{m) Information Gathering Activities}

Students conduct a survey, interview and search in which students were required to use their linguistic resources to collect information.

\section{n) Opinion-Sharing Activities}

Activities where students compare values, opinions, beliefs such as a ranking task in which students list six qualities in order of importance which they might consider in choosing a date or spouse.

\section{o) Information- Transfer activities}

These activities require learner to take information that is presented in one form, and represent it in a different form. For example they may read instructions on how to get from A to B, and they may read information about a subject and then represent it as a graph.

\section{p) Reasoning- Gap Activities}

These activities involve deriving some new information from given information through the process of inference, practical reasoning etc. For example, working out a teacher's timetable on the bases of a given class timetable.

\section{q) Conversation and discussion}

Students are given conversational proposition and are then put into groups which have to prepare arguments either in favor of the proposition or against it.

\section{r) Dialogue}

For some advantages as argued by Byrne dialogue can be practiced at the early stage of the language program.

\section{s) Questionnaires}

Questionnaires is useful because by being pre-planned, they ensure that both questioner and respondent have something to say to each other, and the teacher can act as a resource.

\section{t) Acting from a script}

In this activity, the students act out dialogues the have written by themselves and involve them in coming out to the front of the class.

\section{Classroom questions and classroom interaction}

Classroom teachers' questions have substantial motivational value and are one of the quickest and easiest techniques teachers have for moving their students towards real conversation [43]. Classroom questions are helpful for teachers to manage the class, engage students with the content, and encourage participation, to elicit students' Prior knowledge and to check students understating by using concept checking question.

\section{Teachers' questioning skills}

According to Stevick, one of the most important skills for teacher to develop is the ability to ask effective questions. Kissok Iyortuum also added that the way question is presented is often as important as the questions itself in determine the effect it will have [44].

\section{Methodology}

The main objective of this study was to assess the teachers' application of classroom interaction in developing students speaking skills in Tullu Sangota Primary School grade 8 in focus. This research was designed to describe, analysis and interpret the conditions that exist in relation to teachers' use of classroom interaction. Hence, descriptive survey method was employed on the assumption that it helps to reveal the current issues of teachers' classroom interaction to develop learners' speaking skills.

\section{Subjects of the study}

The study was carried out in one government school in West Shoa Zone, Oromia Regional State in Ambo Bako Tibbe Woreda Tullu Sangota Primary School. This school was selected through purposive sampling based on its convenience. According to the data available, there were one section with the total number of 45 students (18 males and 27 females) and there were four English teachers (2 males and 2 female teachers.

\section{Sampling and sampling techniques}

Grade eight students from the school were the participants of the study. A purposive sampling technique method was employed for selecting the grade level on which the study was carried out. They were selected because these students are the last level to join high school education. The setting sample, Tullu Sangota Primary School, was chosen because it was the place where the researcher's wife has currently been teaching English in the school.

\section{Data collection instruments}

The main objective of this study was to explore the teachers' application of classroom interaction on developing students' speaking skills. The data collection in this research includes collecting information through semi-structured, observation and interviews because the single source of information may not be trusted.

\section{Methods of data analysis}

The data obtained from teachers and students through questionnaires, observation and interview were analyzed using descriptive analysis methods. The data gathered from these instruments have been analyzed in a logical, coherent, and statistical way like table representations (frequency and percentages). Thus, the results of the study were reported using percentages. Observation and interview were analyzed qualitatively. Both open-ended and closed-ended teachers' questionnaires and students' questionnaires, and the teachers' interview were analyzed separately. And the classroom observation is used to support the finding by questionnaires and interviews.

\section{Pilot study}

A pilot study was made to assess the questionnaires and done to get feedback on how the instruments work and whether it works its job or not. After the student-respondents filled the questionnaires, the pilot study helped the researcher to make some possible change. For example, double questionnaires were canceled; ambiguous language was also corrected.

\section{Results and Discussions}

The most appropriate tool used to investigate that is through addressing questionnaires to learners, and classroom observation and teachers' interview. The teachers' interviews are intended to assess the teachers' application of classroom interaction as a pedagogical strategy to enhance the learners' speaking skill. The questionnaires and interview are arranged in order. The students questions required the students to choose 'yes' or 'no' answers, or to choose the appropriate 
Citation: Adaba HW (2017) Exploring the Practice of Teacher-Student Classroom Interaction in EFL to Develop the Learners' Speaking Skills in Tullu Sangota Primary School Grade Eight Students in Focus. Arts Social Sci J 8: 295. doi: 10.4172/2151-6200.1000295

answer from the likert scale choices or open-ended questions requiring them to give their own answers and justify them. The students' questionnaire is aimed at finding out whether the learners give importance and a value to interactions that happen inside the classroom in activating their speaking skill through participating with their classmates or teachers whereas observation checklist aimed at triangulating/checking the students' and teachers' responses in questionnaires and interview respectively (Tables 1 and 2). The teacherrespondents participated in training or workshop on classroom interaction or not. Accordingly, all of the teachers said that they did not participate in any workshop related to importance and how of classroom interaction is useful. During the interview responses some of the teachers said that they had pedagogy courses at university (Table 3 ). As indicated in Table 3 above in the item 9, teachers know the importance and concept of classroom interaction because all (100\%) of them said that strongly agreed that English speaking proficiency is more easily achieved by classroom interaction. The item 10 is designed to identify the concept of teachers about group work in English classroom that it provide opportunities for co-operative relationships to emerge and in promoting genuine interaction among students. The majority of them (75\%) of them agreed on the statement whereas $25 \%$ of them strongly agreed that group working activities are essential in providing opportunities for co-operative relationship and promote interaction among the students. For item 11 accordingly, $75 \%$ of them agreed that group work activities take too long to time to organize and waste a lot of valuable teaching time. The rest of them (25\%) said it was undecided. As Table 3 item 12 item shows, (100\%) of the respondents find that the students do their best when taught as a whole class by their teacher. From item 13 in the Table 3 above we can notice that all percentage of students claims that the teachers' knowledge about the

\begin{tabular}{|c|c|c|c|c|c|}
\hline \multirow{4}{*}{$\begin{array}{l}\text { No } \\
1\end{array}$} & \multirow{4}{*}{$\begin{array}{l}\text { Items } \\
\text { NB: F stands for Frequency and P for percentage } \\
\text { Do you like classroom interaction? }\end{array}$} & \multicolumn{4}{|c|}{ Alternatives } \\
\hline & & \multicolumn{2}{|c|}{ Yes } & \multicolumn{2}{|c|}{ No } \\
\hline & & $\mathbf{F}$ & $\mathbf{P}$ & $\mathbf{F}$ & $\mathbf{P}$ \\
\hline & & 33 & 33 & 77 & 77 \\
\hline \multirow[t]{5}{*}{2} & Do you like to actively participate in the classroom interaction? If you say No, why? & 12 & 12 & 88 & 88 \\
\hline & a. You are not talkative & 7 & 7 & & \\
\hline & b. The topic is not interesting & 22 & 22 & & \\
\hline & c. The teacher does not motivate his students & 18 & 18 & & \\
\hline & d. You fear to make mistakes & 41 & 32 & & \\
\hline 3 & Do you like working with your classmates in classroom interaction? & 50 & 50 & 50 & 50 \\
\hline 4 & Do you think you can improve your speaking ability using classroom interaction? & 48 & 48 & 52 & 52 \\
\hline 5 & Do you like to interact outside the classroom with your classmates? & 28 & 28 & 72 & 72 \\
\hline \multirow[t]{3}{*}{6} & Which type of interaction do you like/enjoy more? & & & & \\
\hline & a. learner-learner interaction & 49 & 49 & & \\
\hline & b. teacher-learner interaction Explain why? & 51 & 51 & & \\
\hline \multirow[t]{4}{*}{7} & Who speak much in the classroom? & & & & \\
\hline & a. students & 17 & 17 & & \\
\hline & b. teachers & 73 & 73 & & \\
\hline & c. both & 11 & 11 & & \\
\hline 8 & Do your teachers give the opportunity to all of the students to interact with them in classroom? & 9 & 9 & 91 & 91 \\
\hline
\end{tabular}

Table 1: Analysis of the frequency of learners' value classroom interaction.

\begin{tabular}{|c|c|c|c|c|c|}
\hline \multirow{3}{*}{$\begin{array}{l}\text { No } \\
1\end{array}$} & \multirow{3}{*}{$\begin{array}{l}\text { Items } \\
\text { Have you ever participated in any training, seminar, workshop or orientation concerning, CLT, especially } \\
\text { classroom interaction? }\end{array}$} & \multicolumn{2}{|c|}{ Yes } & \multicolumn{2}{|c|}{ No } \\
\hline & & $\mathbf{F}$ & $\mathbf{P}$ & $\mathbf{F}$ & $\mathbf{P}$ \\
\hline & & & & 4 & $100 \%$ \\
\hline \multirow[t]{5}{*}{2} & $\begin{array}{l}\text { If your answer to question No. } 6 \text { above is yes', how useful have you found them to implement appropriate } \\
\text { classroom interaction based on the principles of CLT? }\end{array}$ & & & & \\
\hline & a) very useful & & & & \\
\hline & b) moderately useful & & & & \\
\hline & c) useful & & & & \\
\hline & d) Not that much useful & & & & \\
\hline
\end{tabular}

Table 2: Analysis of Teachers' Response if they participated in any Training Related to Implementation of Classroom Interaction.

\begin{tabular}{|c|c|c|c|c|c|c|}
\hline \multirow[t]{2}{*}{ No } & \multirow[t]{2}{*}{ Items } & \multicolumn{5}{|c|}{ Alternatives } \\
\hline & & 5 & 4 & 3 & 2 & 1 \\
\hline 9 & English speaking proficiency is more easily achieved by classroom interaction & $100 \%$ & & & & \\
\hline 10 & $\begin{array}{l}\text { Group work activities are essential in providing opportunities for co-operative relationships to } \\
\text { emerge and in promoting genuine interaction among students }\end{array}$ & $25 \%$ & $75 \%$ & & & \\
\hline 11 & Group work activities take too long to time to organize and waste a lot of valuable teaching time & & $75 \%$ & $25 \%$ & & \\
\hline 12 & Students do their best when taught as a whole class by their teacher & & $100 \%$ & & & \\
\hline 13 & Classroom interaction is helpful in learning speaking skills? & $100 \%$ & & & & \\
\hline
\end{tabular}

Keys: $5=$ strongly agree, 4=Agree, 3=Undecided, 2=Disagree, $1=$ strongly disagree.

Table 3: Conceptual Perspectives of Classroom Interaction. 
importance of classroom interaction in developing speaking skills is clearly all of teachers (100\%) claim that classroom interaction is helpful in learning language skills, specially speaking (Table 4). The finding indicated in Table 4 above indicates that teachers generally have positive attitudes towards communicative English teaching. This is because results from the above item 15 show that $100 \%$ of the teachers thought that it is always important to teach communicative English to students. Similarly, all of teachers agreed during the interview that classroom interaction stimulates students to participate in the class and they can become more competitive. We can understand from the item 14 and 15 that the teachers had a positive attitude towards the importance of teaching about classroom interaction. An attempt was made to ask during interview why the only sometimes teach about classroom interaction to their students. Accordingly, the interviewee teachers complain about the shortage of time and overloaded teaching time. The item 16 indicated that the teachers $(75 \%)$ used classroom interaction sometimes. To this contrary, $25 \%$ of the teacherrespondents said that they always use classroom interaction. The item 17 in the above Table 4, aimed at identifying the frequency of the student likes talking. Accordingly, half of them (50\%) of them said that their students always like to talk in the classroom. In the same way, half of them said that their students sometimes like to talk. For item 18 in Table 4 above, majority of the teachers (75\%) said that they always like to talk in the classroom, and $25 \%$ of them said that they sometimes (Table 5). However, the development of communicative skills can only take place if learners have motivation and opportunity to express their own identity and to relate with the people around them. The teachers' role in the learning process is recognized as less dominant. More emphasis is placed on the learners' contribution through independent learning. For who speak much in English classroom, the item No 21 above revealed that half of the teacher-respondents (50\%) said that the students should speak much sometimes in English classroom. The rest of respondents $(50 \%)$ said that the teachers should speak always. However, Dagarin argues that classroom interaction should be "two ways process between the participants in the language process, the teacher influences the learners and vice versa." The emphasis on communicative interaction provides more opportunities for cooperative relationship to emerge, both among learners and between the teachers and learners. As was observed, Learners made many mistakes. The teachers didn't remind their errors. Errors are regarded with greater tolerance, as a complete normal phenomenon in the development of communicative skills. Classroom management can be seen as the teacher's ability to supportively manage time, space, resources, giving the roles for each of the student and student behaviors to provide a climate that encourages the learning process. For how often the teachers gave the roles for each of the students in a group item 22 in the Table 5 above, all of the teachers (100\%) said that they gave the roles for each of the students in a group. Grouping a higher-level learner with a less proficient learner could help the lower student to improve their level, for instance, a proficient student sometimes provides such as vocabulary or words that make the lower learner concentrates on the task that the whole group is working on [45]. During the interview, the teachers were interviewed how they grouped their students in the classroom. Accordingly, the teachers depended only on 1-5 the school grouping. The teacher 'B' said that "the 1-5 grouping was used throughout the year without any change after

\begin{tabular}{|c|c|c|c|c|c|c|c|c|c|}
\hline \multirow{4}{*}{$\begin{array}{l}\text { No } \\
1\end{array}$} & \multirow{4}{*}{$\begin{array}{l}\text { Items } \\
\text { How often do you teach your students about the value of classroom } \\
\text { interaction? }\end{array}$} & \multicolumn{8}{|c|}{ Alternatives (alert scale) } \\
\hline & & \multicolumn{2}{|c|}{ Always } & \multicolumn{2}{|c|}{ Sometimes } & \multicolumn{2}{|c|}{ Rarely } & \multicolumn{2}{|c|}{ Never } \\
\hline & & $\mathrm{F}$ & $\mathrm{P}$ & $\mathrm{F}$ & $\mathrm{P}$ & $\mathrm{F}$ & $P$ & $\mathrm{~F}$ & $\mathrm{P}$ \\
\hline & & 1 & $25 \%$ & 3 & $75 \%$ & & & & \\
\hline 2 & $\begin{array}{l}\text { How often do you think it is important to teach communicative English to } \\
\text { your students }\end{array}$ & 4 & $100 \%$ & & & & & & \\
\hline 3 & How often do you use classroom interaction? & 1 & $25 \%$ & 3 & $75 \%$ & & & & \\
\hline 4 & How often do your students like to talk? & 2 & $50 \%$ & 2 & $50 \%$ & & & & \\
\hline 5 & How often do you like to talk? & 3 & $75 \%$ & 1 & $25 \%$ & & & & \\
\hline
\end{tabular}

The item No: 1 above indicates that the teachers sometimes teach their students about classroom interaction. This is because $75 \%$ of them said that they taught about classroom interaction in the classroom while $25 \%$ of them said 'always'.

Table 4: Frequency of teachers value of classroom interaction.

\begin{tabular}{|c|c|c|c|c|c|c|c|c|c|}
\hline \multirow{3}{*}{\begin{tabular}{|l|} 
No \\
1 \\
\end{tabular}} & \multirow{4}{*}{$\begin{array}{l}\text { Items } \\
\begin{array}{l}\text { Many of your students participate in the classroom interaction in speaking } \\
\text { classroom? }\end{array}\end{array}$} & \multicolumn{8}{|c|}{ Alternatives (alert scale) } \\
\hline & & \multicolumn{2}{|c|}{ Always } & \multicolumn{2}{|c|}{ Sometimes } & \multicolumn{2}{|c|}{ Rarely } & \multicolumn{2}{|c|}{ Never } \\
\hline & & $\mathrm{F}$ & $P$ & $\mathrm{~F}$ & $P$ & $\mathrm{~F}$ & $P$ & $\mathrm{~F}$ & $\mathrm{P}$ \\
\hline & & & & & & & & & \\
\hline & a. many of them & & & & & & & & \\
\hline & b. some of them & & & 2 & $50 \%$ & & & & \\
\hline & c. few of them & & & 2 & $50 \%$ & & & & \\
\hline 2 & $\begin{array}{l}\text { How often do you invite your students to interact with each other in the } \\
\text { classroom? }\end{array}$ & 4 & $100 \%$ & & & & & & \\
\hline \multirow[t]{4}{*}{3} & Who speak much in your English classroom English? & & & & & & & & \\
\hline & a. Students & & & 2 & $50 \%$ & & & & \\
\hline & b. teachers & 2 & $50 \%$ & & & & & & \\
\hline & c. equally speak & & & & & & & & \\
\hline 4 & How often do you give roles to your students during group work? & 4 & $100 \%$ & & & & & & \\
\hline
\end{tabular}

Item NO: 1 is designed to generate information about how many of their students participate in classroom interaction during speaking skills. In view of that, all of the teachers (100\%) said that some of their students participate in classroom interaction. In similar way, for 20 items all of them (100\%) always invited the students to participate with each other in the classroom. During the interview session, the teacher-respondents responded that their students were not motivated and lack self-confidence.

Table 5: Analysing the Frequency of Classroom Interaction Dimension. 
sometimes improved made" (Table 6). The above table item No 25 showed us that $75 \%$ thought that the relationships they hold with their teachers are very good. Whereas $25 \%$ of them replied that their relationship between their students was good. The teachers' ability to motivate is important because it creates a free-stressed atmosphere and establishes a relationship of mutual confidence and cooperation. This atmosphere is important for English learning because the classroom is a social setting in which relationships influence character traits that reinforce the skills and virtues of effective and responsible students. The students will feel self-confident and will be more able to assume some responsibility for classroom interaction and management when they are exposed to a relaxed and safe place, and as open as possible the space is (Table 7). Nowadays, Communicative Language Teaching uses three kinds of materials. These are text-based (textbooks), task-based (games, role plays), and regalia (signs, magazines, advertisements, and newspapers, or graphic and visual sources). The above Table 7 is intended to identify the frequency of the teachers' use of instructional Materials. Accordingly, majority of them 3(75\%) in item 26 said that they used different games to make students' take turn and speak in the classroom. in contrast to this, only 1 (25\%) said 'rarely'. For item 27 in Table 7 above is intended to understand about how often the sample teachers prepared the culture related simple materials to practice the students speaking skills in the classroom. Accordingly, all of the teachers $4(100 \%)$ said that they sometimes prepare and practice the learners. The item 28 aimed at to check whether the teachers used the instructional activities or not. Based on this, the finding revealed us that the sample teachers did not successfully used them to practice the target language with the students in the classroom. The item 28 (a) showed us that all of the teachers were always depended on the textbook to practice the learners the target language, and they were also used role-plays and simulations. In the same table, the sample teachers were used some of the activities 'sometimes' and they rarely used many of the activities listed in the Table 7 above. If the teachers prepare educational talk like purposeful conversation that enable the students try out new ideas, to hear how they sound, to see what others make of them, to arrange information and ideas into different patterns and where everyone can participate, get respected and get the decisions made jointly. In similar way, said that conversations are part of the socio-cultural activities through which students construct knowledge collaboratively. In addition to this, the teachers can used the content that allows serious discussion and debate about substantive social and global issues will encourage students to consider all sides of an issue and develop critical skills that transfer outside of the classroom. During the open-ended questionnaires, most teachers replied that the most challenging problem a teacher can face is related to the materials, un availability of authentic materials, and lack of time i.e. the teachers were always forced to finish the students textbook not to prepare those activities. An attempt was made to identify whether they adapt the existing material to the students knowledge or not. Accordingly, most of them replied that they did not do that because of awareness and lack of time of overloaded. Item 29 in the above Table 7 is intended to identify whether the students textbook contained the language that teach the learners social purposes or not. Accordingly, $50 \%$ of them replied No' whereas $50 \%$ of them said that the learners textbook contained some of the above social purpose languages. However, the students textbook should contains the language that teaches a variety of social purposes, for example, to entertain, to explain how something works, to provide information, to argue a position, to explore the inner world of the imagination. The teachers' role in promoting foreign language acquisition is very important, as they are responsible for providing students appropriate contexts to foster communicative situations that allow students to express themselves and interact in the target language. Therefore, a careful selection and organization of educational content allows the teacher to include relevant social and educational topics that may interest students and develop their knowledge of the world at the same time that they build up their oral

\begin{tabular}{|c|c|c|c|c|c|c|c|}
\hline \multirow[t]{3}{*}{ No } & \multirow[t]{3}{*}{ Items } & \multicolumn{6}{|c|}{ Alternatives } \\
\hline & & \multicolumn{2}{|c|}{ Yes } & \multicolumn{2}{|c|}{ No } & \multicolumn{2}{|c|}{ Undecided } \\
\hline & & $\mathbf{F}$ & $\mathbf{P}$ & $\mathbf{F}$ & $\mathbf{P}$ & $\mathbf{F}$ & $\mathbf{P}$ \\
\hline 1 & Do you have good relationship with your students? & 3 & $75 \%$ & & & 1 & $25 \%$ \\
\hline 2 & Do you have supportive relationship with students in the classroom? & 4 & $100 \%$ & & & & \\
\hline \multirow[t]{6}{*}{3} & How is your relationship with your teacher? & & & & & & \\
\hline & a. Very good & 3 & $75 \%$ & & & & \\
\hline & b. Good & 1 & $25 \%$ & & & & \\
\hline & c. Sufficient & & & & & & \\
\hline & d. Needs Improvement & & & & & & \\
\hline & e. Not Good & & & & & & \\
\hline
\end{tabular}

Question (1) is put to know whether the teachers had good relationship with their students or not. In view of that, majority of the teacher-respondents (75\%) agreed that they had good relationship with their students. However, $25 \%$ of them said 'undecided' to find out if their teachers were available at any place and time, item No 24 in the above table was asked. Accordingly, all the teachers $(100 \%)$ said that they had supportive relationship with their students out of the classroom and any place and time.

Table 6: Analyze of teachers' relationship with their students.

\begin{tabular}{|c|c|c|c|c|c|}
\hline No & $\begin{array}{l}\text { Instructional Materials Used } \\
\text { Key: 4=always } 3=\text { sometimes } 2=\text { rarely } 1=\text { never }\end{array}$ & 4 & 3 & 2 & 1 \\
\hline 1 & How often do you use different games to make your students' take turn and speak in the classroom? & & $25 \%$ & $75 \%$ & \\
\hline 2 & How often do you practice the learners in the classroom with simple and culture related materials? & & $100 \%$ & & \\
\hline 3 & $\begin{array}{l}\text { Do English textbook contains functional language practice like social purposes like to entertain, to } \\
\text { explain how something works, to provide information, to argue a position? A. yes b. no }\end{array}$ & & & $50 \%$ & $50 \%$ \\
\hline 4 & How often do you prepare your own the text? & & $100 \%$ & & \\
\hline 5 & How often do you adapt the existing materials to the students' culture? & & $50 \%$ & $50 \%$ & \\
\hline 6 & $\begin{array}{l}\text { How often do the activities, methods and strategies you use motivate student to interact in the } \\
\text { English classroom? }\end{array}$ & & & $50 \%$ & $50 \%$ \\
\hline
\end{tabular}

Table 7: Analysis of instructional materials used. 
skills. The above Table 8 is aimed at identifying how often the teachers interrupt their students to correct their error. Accordingly, majority of $(75 \%)$ them said that they always interrupt if their students made mistake (item 33). The rest (25\%) of them said 'sometimes.' For the item 34 in the Table 8 above for the frequency of the students reaction to the teachers interruption, half of the teacher $(50 \%)$ said that their students react to their interruption only sometimes and half of $(50 \%)$ them said that their students react rarely to their feedback interruption For item 35, all of the teacher-respondents (100\%) said that they always provided feedback to their students in the classroom. As Table 4 shows, (75\%) of the respondents find that they told to their students about their mistakes (explicit feedback). On the other hand, $25 \%$ of them said that they reformulate what they said correctly (implicit feedback). Appropriate feedback serves to enhance student learning by bridging the gap between a students' current level and the target goal and by forcing/pushing the student to think or process information in explaining or answering additional questions. As it was shown in the Table 8 above in item 38 , majority of the teachers (75\%) gave feedback at the end of the lesson whereas only $25 \%$ of said corrective feedback should be immediate. Previously done research support that effective feedback is immediate, contingent, corrective and/or specific, and tied to natural settings such feedback serves to control frustration, increase interest and motivation and effort (Swanson et al.) (Table 9). Assessing the speaking Skill is an integral part of instruction that help teachers to design appropriate instructional and allows teachers to provide feedback on learners' performance. An attempt made in item 39 was to identify how often the teachers assessed their students' speaking skills, and how often they allowed their students to assess their classmates speaking skills. Accordingly, all of the teacher-respondents (100\%) replied that they always assessed their students' speaking skills, and majority of them (75\%) for item 40 said that sometimes they allowed their students to assess speaking skills of their classmates. As Table 8 item 41 shows, (100\%) of the respondents find that teachers assessed their students speaking skills at the end of the lesson. The finding of this study showed us that the teachers assess their students' speaking skills at the end of the speaking lesson. Therefore, testing of students' speaking skills should be take place at the beginning and at the end of the most language courses, or during the course itself. For the types of spoken test/assess they used to test/assess their students speaking skills, the last item in the same table, we can notice that the highest percentage of students (100\%) claims that all of the teacher-respondents said that all of them used live monologues to test the spoken of their students. To this contrary, in interview session, the teachers responded that they used only written test. However, Thornbury suggested many types of spoken tests that are commonly used like interviews, live monologues and recorded monologues [46].

\section{Analysis of the students' questionnaires}

Students' attitude, self-motivated role, and participation are vital in the process of learning the target language. Oral skills cannot be properly developed without their active involvement in class activities. Students' participation in classroom interactions can help them enrich their linguistic resources and build their confidence to communicate with others in class or out of classroom in English. The item 1 in the above table is intended to identify the opinion the students had toward classroom interaction. As it can be seen in the Table 1 item 1, majority sounds $(77 \%)$ said that they did not like classroom interaction. In contrary to this, $33 \%$ of them said that they liked the classroom

\begin{tabular}{|c|c|c|c|c|c|c|c|c|}
\hline \multirow[t]{3}{*}{ No } & \multirow{3}{*}{$\begin{array}{l}\text { Perspective on Feedback, Error Correction and Assessments } \\
\text { Keys: } 4=\text { always } 3=\text { sometimes } 2=\text { rarely } 1=\text { never }\end{array}$} & \multicolumn{7}{|c|}{ Alternatives (Alert scale) } \\
\hline & & \multicolumn{2}{|c|}{4} & \multicolumn{2}{|c|}{3} & \multicolumn{2}{|c|}{2} & \multirow[t]{2}{*}{1} \\
\hline & & $\mathbf{F}$ & $\mathbf{P}$ & $\mathbf{F}$ & $\mathbf{P}$ & $\mathbf{F}$ & $\mathbf{P}$ & \\
\hline 1 & How often do you interrupt your students to correct their mistakes? & 3 & 75 & 1 & 25 & & & \\
\hline 2 & How often the students react to your interruption? & & & 2 & 50 & 2 & 50 & \\
\hline 3 & How often do you provide feedback for your students? & 4 & 100 & & & & & \\
\hline 4 & How often do you give feedback focused on the appropriateness? & 3 & 75 & & & & & \\
\hline 5 & How often do you give linguistic form from the students' responses? & 1 & 25 & & & & & \\
\hline \multirow[t]{4}{*}{6} & When do you give feedback? & & & & & & & \\
\hline & a. at the beginning of the lesson & & & 1 & 25 & 3 & 75 & \\
\hline & b. at the end of the lesson & 4 & 100 & & & & & \\
\hline & c. immediately & 1 & 25 & & 25 & 2 & 50 & \\
\hline
\end{tabular}

The above table 8 is aimed at identifying how often the teachers interrupt their students to correct their error. Accordingly, majority of (75\%) them said that they always interrupt if their students made mistake (item 33 ). The rest (25\%) of them said 'sometimes.'

Table 8: Analysis of teachers' error correction and assessment.

\begin{tabular}{|c|c|c|c|c|c|c|c|c|c|}
\hline \multirow[t]{2}{*}{ No } & \multirow{2}{*}{$\begin{array}{l}\text { Assessment Used } \\
\text { Key: } 4=\text { always } 3=\text { sometimes } 2=\text { rarely } 1=\text { never }\end{array}$} & \multicolumn{2}{|c|}{4} & \multicolumn{2}{|c|}{3} & \multicolumn{2}{|c|}{2} & \multicolumn{2}{|c|}{1} \\
\hline & & $\mathbf{F}$ & $\mathbf{P}$ & $\mathbf{F}$ & $\mathbf{P}$ & $\mathbf{F}$ & $\mathbf{P}$ & $\mathbf{F}$ & $\mathbf{P}$ \\
\hline 1 & How often do you assess your students speaking skills? & 4 & 100 & & & & & & \\
\hline 2 & How often do you allow your students to assess their classmates speaking skills? & 1 & 25 & 3 & 75 & & & & \\
\hline \multirow[t]{5}{*}{3} & When do you assess your students speaking skills? & & & & & & & & \\
\hline & A. At the beginning & & & & & & & & \\
\hline & b. at the end & 4 & 100 & & & & & & \\
\hline & c. in the middle & & & & & & & & \\
\hline & d. all of the three & & & & & & & & \\
\hline \multirow[t]{4}{*}{4} & Which types of spoken test your teachers use to test your Speaking? & & & & & & & & \\
\hline & a. interviews & & & & & & & & \\
\hline & b. live monologues & 4 & 100 & & & & & & \\
\hline & c. recorded monologue & & & & & & & & \\
\hline
\end{tabular}

Table 9: Teachers' responses on their use of speaking assessment. 
interaction. For whether learners like to engage actively in the classroom or not, majority of the learners $(88 \%)$ said that they did not like to actively interact in the classroom interaction. In contrary to this, $12 \%$ said they like it. The observation checklist support those students said that they did not like to actively interact in the classroom interaction. They asked also to list some of the reasons why they did not like to participate. They listed that they were unable to speak in English and fear of making mistakes. As it can be seen in the Table 1 item 3 about the students' attitude toward working with peers or groups, they (50\%) relaxed and motivated to work with each other in order to learn speaking skills. The same percent said that they did not relax and did not motivate to work with each other in order to learn speaking skills. For the item 4 'Do you think you can improve your speaking ability using classroom interaction?', majority of the them (52\%) said that they thought that they do not improve their speaking ability using classroom interaction your speaking ability using classroom interaction while $(48 \%)$ of them said 'yes'. For item 5 whether they interacted with their classmates and with their teachers outside the classroom in the Table 1 above, majority of the students $(72 \%)$ said that 'No'. The $28 \%$ said yes'. The study showed also that the learners did not practice the English language by authentic materials. However, authentic materials play a very important role in learning English in the classroom because it is easy for students to communicate in English outside the classroom. During the interview session, the teachers C' said that they could not practice the learners because of lack of time, lack of availability of authentic materials. In similar way, some of the students in their openended questionnaires said (45) what they practice in the classroom did not prepare them for what they use outside the classroom. In similar way, When explaining benefit of interactive class, Brown (1994) said "the task-based activities prepare students for the real world outside of the classroom." However, the idea of Naimat is contrary to this finding. Naimat argue that interaction will strengthen the relationship either among the learners or with their teachers since it gives them the chance to learn from each other and to get feedback on their performance. According to item 6 in the same table, the answers show that majority of the students (61\%) said that they find they enjoy if the teachers only speak in their language class. The rest (39\%) said that they enjoy learner-learner interaction. As Table 1 item 7 shows, for who speak much, all of the students said that their teachers spoke much in the classroom speaking. However, students talk can be used by the students to express their own ideas, initiate new topics, and develop their own opinions. As the result, their knowledge will develop. Students talk will show the activity concentration of the students to their teaching learning activity. For the last item of Table 1 which aimed at identifying whether the teachers gave equal opportunities for all students to interact with the teachers or not, majority of the students said that their teachers did not give equal opportunities to interact with the teachers. The rest of them said 'Yes (Table 10). For item 10, majority (67\%) of the learners liked to speak more during the grammar lesson. To this contrary, $11 \%$ of them liked to speak more when the lesson was reading skills. The same percentage $(10 \%)$ said that they like to speak more when the lesson was speaking skills class and speaking test class. Only $2 \%$ of them said during writing. Item 11 in the Table 2 above is intended to identify whether the teachers treated all language skills or not. Accordingly, majority sound (91\%) neither said that their teachers did nor treats all language skills equally whereas only $9 \%$ of them said 'yes. The last item in the Table 2 above was intended to identify which language skill their teachers relied on. Based the result, $83 \%$ of them said that their teachers relied on grammar. On the other hand, $17 \%$ of them said that their teachers relied on reading skills. The Table 11 item 1 show us that majority of the student-respondents (68\%) said teachers allowed their students participate in classroom interaction. $24 \%$ of them said that their teachers allow them to interact in the classroom. On the other hand, $8 \%$ of them said 'rarely. However, making the students to interact with teacher and among their fellows in the classroom will build their knowledge as well as their confidence. Interaction is an essential social activities for students through which they not only construct knowledge, but also build confidence and identity as competent language users [47]. For item 14 above is intended to identify whether the teachers taught their students about interaction or not. Accordingly, very majority of the respondents (89\%) said that their teachers rarely taught them about classroom interaction. Whereas

\begin{tabular}{|c|c|c|c|}
\hline \multirow[t]{2}{*}{ No } & \multirow{2}{*}{$\begin{array}{l}\text { Items } \\
\text { Key: } P=\text { percentage } F=\text { frequency }\end{array}$} & \multicolumn{2}{|c|}{ Responses } \\
\hline & & $\mathbf{F}$ & $\mathbf{P}$ \\
\hline \multirow[t]{6}{*}{1} & Which language skill do you like most to improve? & & \\
\hline & a. listening & 8 & 8 \\
\hline & b. speaking & 48 & 48 \\
\hline & c. reading & 14 & 14 \\
\hline & d. writing & 12 & 12 \\
\hline & e. grammar & 18 & 18 \\
\hline \multirow[t]{6}{*}{2} & When do you like to speak more? & $\mathrm{F}$ & $\mathrm{P}$ \\
\hline & a. during speaking class & 10 & 10 \\
\hline & b. during speaking test & 10 & 10 \\
\hline & c. during grammar lesson & 67 & 67 \\
\hline & d. during reading lesson & 11 & 11 \\
\hline & e. during writing skills lesson & 2 & 2 \\
\hline \multirow[t]{3}{*}{3} & Do your teachers treat all languages equally? & $\mathrm{F}$ & $\mathrm{P}$ \\
\hline & a. yes & 9 & 9 \\
\hline & b. no & 91 & 91 \\
\hline \multirow[t]{6}{*}{4} & Which language skills do your teachers most of the times rely on? & & \\
\hline & a. listening & & \\
\hline & b. speaking & & \\
\hline & c. reading & 17 & 17 \\
\hline & d. writing & & \\
\hline & e. grammar & 83 & 83 \\
\hline
\end{tabular}

Table 10: Analysis of the students' responses on their language skills preference. 


\begin{tabular}{|c|c|c|c|c|c|c|c|c|}
\hline \multirow[t]{3}{*}{ No } & \multirow{3}{*}{$\begin{array}{l}\text { Items } \\
\text { NB: } F \text { stands for Frequency and } P \text { for percentage }\end{array}$} & \multicolumn{7}{|c|}{ Reponses } \\
\hline & & \multicolumn{2}{|c|}{4} & \multicolumn{2}{|c|}{3} & \multicolumn{2}{|c|}{2} & 1 \\
\hline & & $\mathbf{F}$ & $\mathbf{P}$ & $\mathbf{F}$ & $\mathbf{P}$ & $\mathbf{F}$ & $\mathbf{P}$ & \\
\hline 1 & How often your teachers allow you to participate in classroom interaction? & 24 & 24 & 68 & 68 & 8 & 8 & \\
\hline 2 & How often do your teachers teach you about the value of classroom interaction? & 2 & 2 & 9 & 9 & 89 & 89 & \\
\hline 3 & $\begin{array}{l}\text { How often your teachers give you the opportunity to interact (give and take) with them } \\
\text { outside classroom interaction? }\end{array}$ & 7 & 7 & 64 & 64 & 29 & 29 & \\
\hline \multirow[t]{2}{*}{4} & \multirow[t]{2}{*}{ Do you think you can improve your speaking ability using classroom interaction? a. yes b. no } & \multicolumn{2}{|c|}{ Yes } & \multicolumn{2}{|c|}{ No } & & & \\
\hline & & \multicolumn{2}{|c|}{89} & \multicolumn{2}{|c|}{11} & & & \\
\hline
\end{tabular}

Table 11: The Frequency of the students' responses on the teachers' value of classroom interaction.

\begin{tabular}{|c|c|c|c|c|c|c|c|c|c|}
\hline \multirow[t]{3}{*}{ No } & \multirow{3}{*}{$\begin{array}{l}\text { Items } \\
\text { NB: F stands for Frequency and } P \text { for percentage }\end{array}$} & \multicolumn{8}{|c|}{ Alternatives } \\
\hline & & \multicolumn{2}{|c|}{4} & \multicolumn{2}{|c|}{3} & \multicolumn{2}{|c|}{2} & \multicolumn{2}{|c|}{1} \\
\hline & & $\mathbf{F}$ & $\mathbf{P}$ & $\mathbf{F}$ & $\mathbf{P}$ & $\mathbf{F}$ & $\mathbf{P}$ & $\mathbf{F}$ & $\mathbf{P}$ \\
\hline 17 & $\begin{array}{l}\text { How often do your teachers use different games in } \\
\text { speaking classroom? }\end{array}$ & & & & & 69 & 69 & 31 & 31 \\
\hline \multirow[t]{9}{*}{18} & $\begin{array}{l}\text { Which of the following things your teachers use in the } \\
\text { classroom? tick in front of them }\end{array}$ & & & & & & & & \\
\hline & a. Handouts & & & & & 100 & 100 & & \\
\hline & b. magazines & & & & & & & 100 & 100 \\
\hline & c. hotel menus & & & & & & & 100 & 100 \\
\hline & d. Newspaper & & & & & & & 100 & 100 \\
\hline & e. advertisement & & & & & & & 100 & 100 \\
\hline & f. television & & & & & & & 100 & 100 \\
\hline & g. picture & & & & & 100 & 100 & & \\
\hline & H. only text books & 100 & 100 & & & & & & \\
\hline
\end{tabular}

Key: $4=$ always $3=$ sometimes $2=$ rarely $1=$ never.

The item 1 and 2 in the Table 12 is aimed at identifying how often their teachers used instructional activities in the classroom interaction during speaking skills. The result show us that the teachers rarely used games and other instructional activities. For the last choice ' $\mathrm{H}$ ', all of the students said that the teachers always used textbooks during speaking class.

Table 12: Analysis of students' response on the teachers' use of instructional activities.

$9 \%$ and $2 \%$ of them said that sometimes and always respectively. However, Cotter explains that training in oral skills which let them communicate and interact in a meaningful and fruitful form. This can be done by exchanging information, negotiating meaning, supporting ideas, facing oral defenses) is a way to motivate students to perceive the foreign language as a tool for social interaction. For item No 15, majority of the student-respondents (64\%) said that their teachers gave them the opportunity to interact only sometimes with them (teachers) in classroom interaction. The rest of them $29 \%$ and $7 \%$ said 'rarely' and 'always.' The students need to be aware of how to use classroom interaction and how to repair communication breakdowns, how to deal with those who dominate the conversation, how to use language to solve problems, and how to start end a discussion. The item 4 in the Table 11 above showed that the students were aware about they can improve their speaking ability using classroom interaction. This is why $89 \%$ of the students said 'yes' while $11 \%$ of them said 'No' (Tables 12 and 13). Teachers should consider what methodology they will use, the technique they should apply as well as the specific activities they will introduce to cover a topic when planning a language lesson. In Table 12 item 1 above, intended to identify the frequency of the teachers' classroom activities, methods and strategies were motivated the students. Based on the analysis, $58 \%$ of the respondent said it was sometimes that the activities, the methods and strategies were motivated, and engaged the students in the classroom participate and enhance learning speaking skills. To this contrary, $29 \%$ and $14 \%$ student-respondents said rarely and always respectively. From the majority response, teachers are responsible to offer to students the best methods and activities to better help them feel engaged in classroom.
During the open-ended questions, the student-respondents relied that some teachers still follow traditional approach. Students' culture related texts help the learners to transfer what they learn in the classroom to the outside world and to expose students to natural language in a variety of situations because it is easy for students to understand the aim of teaching and learning. For item 20 in the above Table 5 is intended to identify how often their teachers practice them speaking skills with real life related materials. Based on the students' sounds, the teachers sometimes practiced them speaking by real life related materials. This was why the majority of the students (58\%) said sometimes and the rest of $14 \%$ and $29 \%$ of them said always and rarely respectively. If the teachers and students work together, they can create the intellectual and practical activities that shape and advance their knowledge in the target language as well as the processes and outcomes of individual development. The finding of this study (Table 5, item 21) revealed us that the teachers and students did not work together to provide activities that involve interaction between learners because majority $(64 \%)$ of the respondents said that their teachers never involved them in preparing or deciding the types, contents and structure of the activities. The left percent i.e. 36\% said rarely. However, Scrievener commented that the aim of communicative activity in class should get learners to use the language they are learning to interact in realistic and meaningful ways. For item 22, we can notice that the highest percentage of students $(90 \%)$ claims that their teachers only used the textbook to practice speaking skills. In contrary to this, only $10 \%$ said sometimes. As Table 5 item 23 shows, (73\%) of the respondents find that the contents of the English textbooks related to their culture. The rest of respondents $27 \%$ and $9 \%$ said always and rarely. The item 24 


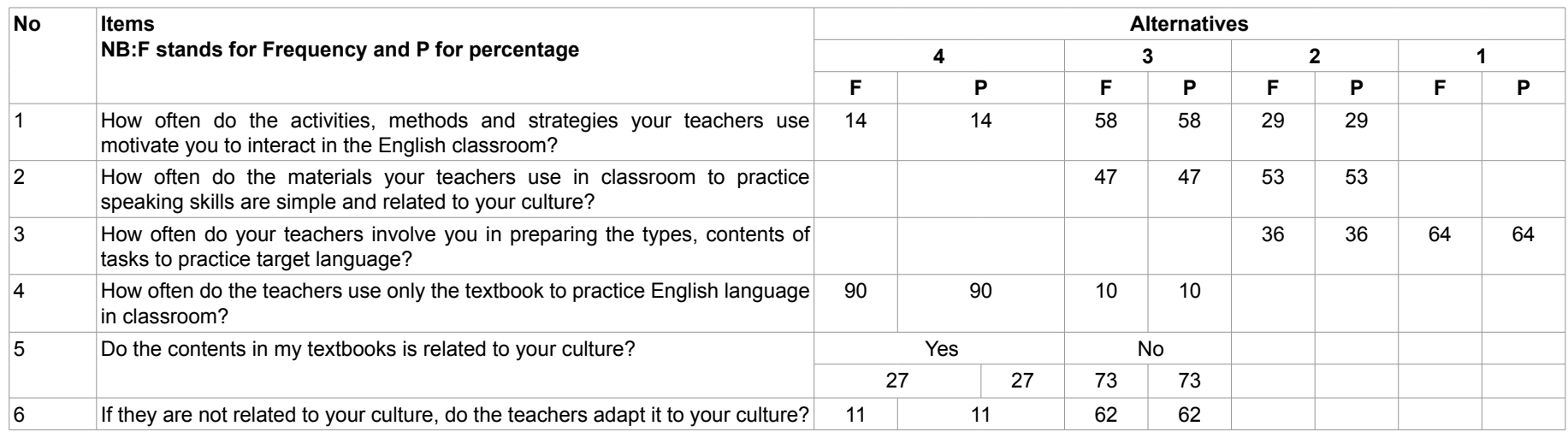

Table 13: Analysis of the students' response on the teachers' use of simple and culture-related materials in classroom to practice the learners speaking skills.

\begin{tabular}{|c|c|c|c|c|c|c|c|c|c|}
\hline \multirow[t]{3}{*}{ No } & \multirow{3}{*}{$\begin{array}{l}\text { Assessment Used } \\
\text { Key: 4=always } 3=\text { sometimes } 2=\text { rarely } 1=\text { never }\end{array}$} & \multicolumn{8}{|c|}{ Alternatives } \\
\hline & & \multicolumn{2}{|c|}{4} & \multicolumn{2}{|c|}{3} & \multicolumn{2}{|c|}{2} & \multicolumn{2}{|c|}{1} \\
\hline & & $\mathbf{F}$ & $\mathbf{P}$ & $\mathbf{F}$ & $\mathbf{P}$ & $\mathbf{F}$ & $\mathbf{P}$ & $\mathbf{F}$ & $\mathbf{P}$ \\
\hline 1 & How often do your teachers assess your speaking skills? & & & 29 & 29 & 71 & 71 & & \\
\hline 2 & $\begin{array}{l}\text { How often do your teachers allow you to assess your classmates' speaking } \\
\text { in classroom? }\end{array}$ & & & 15 & 15 & 69 & 69 & 16 & 16 \\
\hline \multirow[t]{5}{*}{3} & When do your teachers assess your speaking skills? & & & & & & & & \\
\hline & A. At the beginning & & & & & & & & \\
\hline & b. At the end & 100 & 100 & & & & & & \\
\hline & c. In the middle & & & & & & & & \\
\hline & d. All of the three & & & & & & & & \\
\hline \multirow[t]{5}{*}{4} & $\begin{array}{l}\text { How often do your teachers use the following types of spoken to test your } \\
\text { speaking? }\end{array}$ & & & & & & & & \\
\hline & a. Interview & & & & & 100 & 100 & & \\
\hline & b. Written spoken test & 100 & 100 & & & 100 & 100 & & \\
\hline & c. Live monologues & & & & & 100 & 100 & & \\
\hline & Recorded monologue & & & & & 100 & 100 & & \\
\hline
\end{tabular}

Table 14: Analysis of the frequency of teachers of assessment in speaking class.

was intended to check whether their teachers adapt the existing text to the students' culture or not. Accordingly, majority of the students $(62 \%)$ said that their teachers rarely adapt the existing text to the students' culture whereas $11 \%$ 'No' (Table 14). Assessing the speaking Skill is an integral part of instruction that help teachers to design appropriate instructional and allows teachers to provide feedback on learners' performance. However, the student-respondents' replied in different ways. This is why majority $(71(\%)$ of them said that their teachers rarely assessed their students' speaking skills, and they sometimes (29\%) allowed their students to assess their classmates (item 25). The observation checklist support the student-respondents' that the teachers sometimes assessed their students' speaking skills and they rarely allowed their students to assess their speaking skills. Therefore, assessment should be used either by the teacher in classroom or by the students to assess themselves in order to provide feedback about the teaching and learning activities. An attempt was made to identify how often the teachers allow their students to assess their classmates speaking skills in item 26. Accordingly, all of the teacher-respondents (100\%) replied that they assessed their students' speaking skills, and majority of them $(75 \%)$ said that they allowed their students to assess speaking skills of their classmates. However, the student-respondents' replied in different ways. This is why majority (71(\%) of them said that their teachers sometimes assessed their students' speaking skills, and they rarely allowed their students to assess their classmates. The observation checklist support the student-respondents' that the teachers sometimes assessed their students' speaking skills and they rarely allowed their students to assess their speaking skills. Therefore, assessment should be used either by the teacher in classroom or by the students to assess themselves in order to provide feedback about the teaching and learning activities. For item 27 in Table 6 above, all of the student-respondents said that their teachers assessed their speaking skills at the end of the class. Item No 28 of Table 5 of the students' questionnaires aimed at identifying the types of spoken test/assess they used to test/assess their students speaking skills. Accordingly, all of the student-respondents said that (Table 15) the students who have positive and warm relationships with teachers and peers demonstrate higher levels of achievements and higher social relationships because the quality of relationships between the students and teachers can determine the quality of the interaction. The information obtained from the Table 7 item 29 show us that the students and teachers had sometimes they had good relationship while the rest of them (43\%) of them said always whereas $57 \%$ of them said that their teachers had always relationship with them. The above Table 7 items No 30 showed us that $78 \%$ thought that the relationships they hold with their teachers are very good. The surveyed students explained that the relationship they hold with their teachers help them to improve their motivation, help them to interact with their teachers, and encourage them to ask teachers for help and support whenever they need. Four students said that "by having a good relationship with their teachers, students tend to be more interested in the learning process and also they behave well." Another one said: "students who are interested for their learning and performance have to approach their teachers and have a good 


\begin{tabular}{|c|c|c|c|c|c|c|c|c|c|}
\hline \multirow[t]{3}{*}{ S. No } & \multirow[t]{3}{*}{ Items } & \multicolumn{8}{|c|}{ Alternatives (alert scale) } \\
\hline & & \multicolumn{2}{|c|}{4} & \multicolumn{2}{|c|}{3} & \multicolumn{2}{|c|}{2} & \multirow{2}{*}{$\begin{array}{l}1 \\
F\end{array}$} & \multirow[b]{2}{*}{$\mathbf{P}$} \\
\hline & & $\mathbf{F}$ & $\mathbf{P}$ & $\mathbf{F}$ & $\mathbf{P}$ & $\mathbf{F}$ & $\mathbf{P}$ & & \\
\hline 1 & How often do your teachers have good relationship with you? & 43 & 43 & 57 & 57 & & & & \\
\hline \multirow[t]{4}{*}{2} & How is your relationship with your teacher? & & & & & & & & \\
\hline & a. Very good & 8 & 8 & & & & & & \\
\hline & b. Good & 78 & 78 & & & & & & \\
\hline & c. Sufficient & 14 & 14 & & & & & & \\
\hline 3 & $\begin{array}{l}\text { How often do your teachers hold a supportive relationship with } \\
\text { students in the classroom? }\end{array}$ & 20 & 20 & 69 & 69 & 11 & 11 & & \\
\hline
\end{tabular}

Table 15: Analysis of the students' responses to the relationship that exists between students and teachers.

\begin{tabular}{|c|c|c|c|c|c|c|c|c|c|}
\hline \multirow{4}{*}{\begin{tabular}{|l|} 
No \\
32 \\
\end{tabular}} & \multirow{4}{*}{$\begin{array}{l}\text { Items } \\
\text { Perspective on Feedback } \\
\text { Do your regular classroom interactions help you to reduce your speaking mistakes } \\
\text { with justifying the answer? }\end{array}$} & \multicolumn{8}{|c|}{ Alternative (yes-no) } \\
\hline & & \multicolumn{2}{|c|}{ Yes } & \multicolumn{5}{|c|}{ No } & \\
\hline & & $\mathbf{F}$ & $\mathbf{P}$ & $\mathbf{F}$ & \multicolumn{3}{|c|}{$\mathbf{P}$} & & \\
\hline & & 100 & 100 & & & & & & \\
\hline 33 & Do your teachers use signs and feedback & 69 & 69 & 31 & \multicolumn{3}{|c|}{31} & & \\
\hline 34 & Do your teachers teach you that making mistake is part of learning? & 43 & 43 & 57 & \multicolumn{3}{|c|}{57} & & \\
\hline \multirow[t]{2}{*}{ No } & \multirow{2}{*}{$\begin{array}{l}\text { Perspective on Feedback continued } \\
\text { Keys: } 4=\text { always } 3=\text { sometimes } 2=\text { rarely } 1=\text { never }\end{array}$} & \multicolumn{2}{|c|}{4} & \multicolumn{2}{|c|}{3} & \multicolumn{2}{|c|}{2} & \multicolumn{2}{|c|}{1} \\
\hline & & $\mathbf{F}$ & $\mathbf{P}$ & $\mathbf{F}$ & $\mathbf{P}$ & $\mathbf{F}$ & $\mathbf{P}$ & $\mathbf{F}$ & $\mathbf{P}$ \\
\hline 35 & $\begin{array}{l}\text { If you say 'yes' for question No } 33 \text { above, how often do your teachers interrupt } \\
\text { you to correct your mistakes? }\end{array}$ & 20 & 20 & 49 & 49 & & & & \\
\hline 36 & $\begin{array}{l}\text { If you say 'yes' for question No } 33 \text { above, how often do you react to your } \\
\text { teachers interruption? }\end{array}$ & & & 52 & 52 & 17 & 17 & & \\
\hline \multirow[t]{3}{*}{37} & When do you become effective communicators in the foreign language? & & & & & & & & \\
\hline & a. When your teacher give feedback focused on the appropriateness. & 61 & 61 & & & & & & \\
\hline & b. when your teacher give linguistic form from the your' responses & 39 & 39 & & & & & & \\
\hline \multirow[t]{4}{*}{38} & When do your teachers give you feedback? & & & & & & & & \\
\hline & a. at the beginning & & & & & & & & \\
\hline & b. at the end of the lesson & 100 & 100 & & & & & & \\
\hline & c. immediately & & & & & & & & \\
\hline
\end{tabular}

Table 16: Analysis of students responses on the teacher's feedback provided.

relationship with them." Contrarily, one student pointed that the relationship he holds with their teachers need improvement. He said: "I do not have a good relationship with my teacher, and I do not feel free to ask them for help because it is not part of my culture, teachers are the only one who has voice inside the classroom." To find out if their teachers were available at any place and time, the following questions was asked: 'How often do your teachers hold a supportive relationship with students in the classroom?' The kinds of relationship teachers hold with students out of the classroom was always had good relationship and they were supportive to their students any place and time (teachers' responses). According to the students surveyed 20\% said that their teachers always hold a supportive relationship with the students. Majority sound (69) said that their teachers were supportive only sometimes whereas $11 \%$ of them said 'rarely'. Question (1) is put to know whether regular interaction in classroom helps students to reduce their speaking mistakes with justifying the answer. Based on the analyses, all of the students thought that the regular classroom interactions help them to reduce their speaking mistakes with justifying the answer. For item 2 in the above Table 16, for whether their teachers used signs and feedback during speaking skills, majority (69\%) of the students said yes', and $31 \%$ of them said 'no. In similar way, others scholars agree on the finding. For example, (Swanson et al., 1999) commented that cueing and feedback provides some helps to students in answering questions. Feedback encompasses correcting students, and offering them an assessment of how well they have done. As Table 16 shows, (57\%) of the respondents find that their teachers did not teach them about making mistake is part of learning. The rest $43 \%$ were not agree on the statement. In learning foreign language, the students should know that when they make mistake, they should know that they may progress because language learning, especially spoken English learning is compared to learning to ride a bike or learning how to play musical instrument. Item 4 the above Table 8 is aimed at identifying when the teachers provide corrective feedback and appropriate assessment for speaking learning. According to the analysis, it appears from the Table 8 that $61 \%$ of respondents said that their teachers preferred to correct their students explicitly, and tell them about their mistakes and correct it, whereas the others $39 \%$ said that their teachers preferred the implicit one and reformulate what they said indirectly. As it was shown in the table item 5 , all (100\%) of the student-respondents said that their teachers gave feedback at the end of the lesson. However, effective feedback should be immediate, contingent, corrective and specific, and tied to natural settings such feedback serves to control frustration, increase interest and motivation and effort. Question item 1 was intended to ask their opinion of working with group. Accordingly, $58 \%$ which is majority is said that they did not like working with group in the classroom. The rest percent $42 \%$ said that they liked working with groups in classroom activities (Table 17). Item 1 is intended to identify whether their teachers gave a role for each of the students or not. The majority of the students (81\%) said that their teachers did not give roles for the students in a group. Only $19 \%$ of them agreed on the statement. The observation checklist support for the majority sound because majority of students did not participate in classroom since the teachers did not roles for each member in the group. Each student did feel responsible for the success of the whole group. For item 41 for 


\begin{tabular}{|c|c|c|c|c|c|}
\hline \multirow[t]{3}{*}{ No } & \multirow[t]{3}{*}{ Item } & \multicolumn{4}{|c|}{ Alternatives (yes-no) } \\
\hline & & \multicolumn{2}{|c|}{ Yes } & \multicolumn{2}{|c|}{ No } \\
\hline & & $\mathbf{F}$ & $\mathbf{P}$ & $\mathbf{F}$ & $\mathbf{P}$ \\
\hline 1 & Do you like working in group? & 42 & 42 & 58 & 58 \\
\hline 2 & Do your teachers give you roles for each of the students during group work? & 19 & 19 & 81 & 81 \\
\hline 3 & $\begin{array}{l}\text { Do the groups in the classroom varied social backgrounds, intellectual skills, and physical capabilities work } \\
\text { together? }\end{array}$ & 23 & 23 & 77 & 77 \\
\hline 4 & Do every members of group work toward and solve problems and complete tasks. & 10 & 10 & 90 & 90 \\
\hline 5 & Do your teachers inform you the objectives of the lesson? & 7 & 7 & 93 & 93 \\
\hline
\end{tabular}

Table 17: The extent of teachers' use of cooperative learning.

whether the learners in the group were varied social backgrounds, intellectual skills, and physical capabilities work together to learn subject matter, solve problems, and accomplish tasks. Accordingly, $77 \%$ of the student-respondents said that the group did not varied social backgrounds, intellectual skills, and physical capabilities. The rest of them $33 \%$ said no'. Harmer suggests by streaming weak participators in groups and letting them work together, the teacher can achieve a high level of participation in a group. Cooperative learning means that every member of the group is included, and differences among group members are resolved by the group members. However, the item 2 in Table 9 contradicts with this idea because majority (90\%) of the students said every members of group did not work toward and solve problems and complete tasks. Only $10 \%$ was agreed on the statement. In the last question 3 the students are asked whether the teachers inform the students the objectives of the topic or not.

\section{Analysis of students' and teachers open-ended questionnaires}

As far as the factors affecting classroom interaction are concerned, the teachers listed the following factors. For the speaking problems students most face in oral expression, the teachers explained the followings:

a) Large class size.

b) Shyness, anxiety and stress.

c) Low proficiency of the learners in the English language.

d) Teaching methodology is the most hindrance in implementing CLT. In addition to that, the majority of the English teachers had limited experiences about CLT and they had used traditional type or teacher-centered English teaching methodology.

e) Fear of making mistakes.

f) Nothing to say about the chosen topic.

g) Limited vocabulary knowledge.

h) Poor understanding of the language/ students' low proficiency in the English language.

i) Low participation.

j) Failures of the learners to use the language outside the classroom.

k) Mother tongue use.

l) Lack of background knowledge.

m) Family background.

n) Lack of or low confidence.

o) Lack of enough time. p) Parents' expectation of a teacher is the only teacher of their children.

q) Lack of appropriate activities in the students' textbook.

r) Failures of the learners to use the language outside the classroom.

s) Different learners' learning styles.

t) The low proficiency of the learners in the English language.

u) Textbook lack of basis of certain communicative functions.

v) Lack training by government or concerned body.

In addition to this, the observation checklist showed us that the majority of the English teachers had limited experiences about CLT and they had used traditional type or teacher-centered English teaching methodology. An attempt was made to ask in interview why they were used traditional approach. They reason out that some of the teachers did not attend pedagogy courses as they graduated in applied sciences. From the above teachers' open-ended questionnaires, the respondents listed that one problem of practicing interaction in the classroom was that the textbook lacks some basis of certain communicative functions, such as apologizing, describing, inviting, promising etc. that the ESL learners need to know. It is teacher's responsibilities to create a freestressed atmosphere and establishes a relationship of mutual confidence and cooperation. The students can feel self-confident and will be more able to assume some responsibility for classroom interaction and management when they are exposed to a relaxed and safe place [48].

Analysis of teachers' interview: The findings obtained through interview were consistent result with findings of the teachers' and the students' questionnaires and the observation checklists. An interview was held with four English teachers. The type of interview used was semi-structured interview. Seven leading questions presented below were raised with relevant probes to address these themes.

1. What do you think about classroom interaction (CI) is? How do you define it in your own words?

2. Do you think using CI has advantages in the speaking learning process?

3. How do you evaluate the practicability of $\mathrm{CI}$ in your classrooms?

4. What are the roles of the teacher in the classroom interaction?

5. Would you mention some of the techniques and activities you used in CI class?

6. How could you involve passive learners in classroom participation?

7. What are the problems hindering implementing $\mathrm{CI}$ in class?

8. Do you adapt the existing materials to the students' culture? 
The interview result proved that teachers were aware of classroom interaction. However, the samples replied that they complain the application of appropriate CL. One of the teachers, for example, defined $\mathrm{CI}$ as follows:

The other teacher defined it as follows: Classroom interaction is the process in which the students do things together in the classroom work so that they can learn from each other's... the aim of classroom interaction is to make the learner's active participation. The purpose of the third interview question was to elicit information pertaining to the interviewees' application of CI in their classrooms. Accordingly, all of the teachers $(100 \%)$ of them responded that engaging the learners' in to classroom participation is difficult because the students lack language to speak and back ground knowledge. In addition to this, their students prefer learning the grammar than other language skills. Teacher B' said that primary school learning was depending on memorization than communication. Therefore, when they come to high school, they have too much difficulty to adjust themselves to the language learning and teaching practices. With regard to this, one of these teachers forwarded the following. In addition to this teacher $C^{\prime}$ added that what they learned at primary school affects their classroom interaction at high school.

The teacher D' explained that CI is very important, but it is difficult to put in to practice for many reasons like large class size, work load of teachers, lack of teaching material, lack of interest, budget, technology, lack of training on such methodology, overcrowded classes, etc. In the interviewees', three of the respondents expressed their concerns regarding the fact that most students have poor language skills. In most schools, English is still taught with traditional methods. 'How often do you prepare the students' culture related material?' Almost all of the teachers expressed that they couldn't prepare additional materials. They responded that they had no time to prepare simple materials. Another teacher on the other hand put his perception of preparing simple materials because their school required them to complete the curriculum. The teacher C' was asked the same questions. I think we do sometimes because we prepare the reading passage for exam. However, the English examinations are practically testing grammatical and vocabulary knowledge of students. There is also a number of reading comprehension questions too. Yet, speaking, listing or writing skills are not assessed in those multiple-choice items of tests. The purpose of the fourth interview question was to elicit information pertaining to the interviewees' roles during CI. The question said "What the role of the teacher in the classroom interaction?"

Almost all of them responded teachers' role in CI as follows:

- Providing different activities.

- Facilitating the interaction.

- Giving feedback and corrections.

- Assess the learners' speaking.

- Encouraging students.

- Grouping the learners.

This clearly shows that all the respondents have a clear awareness about the role of the language teachers. Nevertheless, they couldn't put $\mathrm{n}$ to practice effectiveness. For fifth questions furthermore, the interviewees were asked about their perception of some the techniques and activities they used in CLT class, all the interviewees said that they used some of the techniques and activities in the classroom and believed that it is essential to utilize them CLT to improve students' English language ability. Concerning the sixth interview question on how they involve passive learners in classroom participation, almost all of the interviewees mentioned that many students were passive learners. In addition to this, they mentioned that they feel a little bit shy; they feel uncomfortable when they are asked to speak in English. They feel reluctant to speak in front of the whole class. The interviewees used some techniques to involve passive learners in classroom interaction. These are: They make them speak within pairs or groups before asking them to speak in front of the whole class. The teachers were also asked whether they used interactive activities or not. Based on the interview question, teacher ' $A$ ' replied that "...the interactive activity require learners' participation and involvement and provide opportunities." This show us that the teachers aware about interactive. An attempt was also made to identify how often they use it in their language classroom. Accordingly, he replied that he did not use it because of lack of time. The other teachers replied the same answer that they had lack of time to use things out of the students textbook. The interview results showed that the motivation behind participation of some students in class is in order to have a good grade in participation. According to them, the grade is one of the most important factors to participate in class. Therefore, the teachers must aware that the students are more motivated if they are exposed to activities to which encourage them to use the target language because the students were not interact in the class oral skills class in order to improve their communicative skills. The interview result also showed us that the students' fears of making errors and losing respect in front of their classmates as factors that might influence students' willingness to interact in class oral activities. Due to inaccurate pronunciation or grammar as possible negative influence in their motivation in participation, the learners perceived fears about making mistakes or maybe being laughed at by other. Therefore, it is the teachers' responsibilities to create a supportive environment in the class and encourage respect among students, and to strengthen the students' confidence when speaking or doing oral presentations in front of others where their attention is more focused on communicating content than in the accuracy of their speech [49-51].

\section{Factors affecting students' participation in the class}

The student-respondents replied that one of the teachers' problems was that they always want to rely on the teaching of grammar. However, the teachers should teach grammar by insisting the grammatical rules unless they are applied to real-life situations. The data from the interviews showed that the majority of the participants were highly aware of the importance of active participation in class activities as a way of improving their oral performance. Attitudes and motivation play an important role when students are learning a foreign language as they strongly affect their success or lack of it in their learning process. The teachers reported that the students had not interest in classroom interaction. However, the students need to be conscious of the necessity of using the target language to communicate because when learners have a clear communicative need in the target language, they are most likely to learn language spontaneously by participating in class activities. The interview results showed that the motivation behind participation of some students in class is in order to have a good grade in participation. According to them, the grade is one of the most important factors to participate in class. Therefore, the teachers must aware that the students are more motivated if they are exposed to activities to which encourage them to use the target language because the students were not interact in the class oral skills class in order to improve their communicative skills. The interview result also showed us that the students' fears of making errors and losing respect in front of their classmates as factors 
that might influence students' willingness to interact in class oral activities. Due to inaccurate pronunciation or grammar as possible negative influence in their motivation in participation, the learners perceived fears about making mistakes or maybe being laughed at by other. Therefore, it is the teachers' responsibilities to create a supportive environment in the class and encourage respect among students, and to strengthen the students' confidence when speaking or doing oral presentations in front of others where their attention is more focused on communicating content than in the accuracy of their speech.

\section{Conclusions}

To assess teachers application of classroom interaction in developing the students speaking skill the researcher considered many aspects like teachers' roles, students' roles, the implementation of classroom interaction, problems students face and the value of classroom interaction, etc. To gather reliable information with regard to the above aspects, the researcher used observation, questionnaire, and interview. It has been found from the data that the teachers in the sample do not teach speaking through pairs and small groups though they forwarded a contradicting opinion in the interview. In addition to this, they did not act as facilitators, advisors and coordinators. It has been also observed that the teachers did not diagnose problems students face unless they are asked for help. The students also did not actively participate during the speaking activities because lack of background knowledge, attitudinal problems, fear of making mistakes, lack of confidence and lack of personal motivation. The finding revealed us that communicative activities like storytelling, interview and debating, role play, simulation, interview, language games and information gap activities, dialogues, debates and discussions, presentations, role-plays, simulations, telling stories were not presented during the classroom interaction in speaking sessions. The teachers spent most of their time depending on the students' textbooks in English class. Because of this, students could not communicate what they learn in language class to outside classroom. Both of teachers and learners aware about the importance of classroom interaction in leaning and acquiring knowledge, but they complain the application of it. During grouping the learners in the classroom speaking, the teachers did not use different books by considering the types of learners (age, interest/hobbies, cultural/ ethical background, previous knowledge, linguistic proficiency, etc. Most teachers' feedback focused on appropriateness, they tried to correct the learners' error for much time. However, Esberger said that 'the person who never made a mistake, never made anything." So when students know that they have made a mistake, they should know that they have made progress. In addition to this, the teacher assesses his students' speaking skills at the end of the speaking lesson.

\section{References}

1. Allwright $R$ (1984) The Importance of Interaction in Classroom Language Learning.

2. Allwright D, Baily KM (1991) Focus on the Language Classroom. Oxford: Oxford University Press.

3. Allwright D, Bailey K (1991) Focus on the Language Classroom: An introduction to classroom research for language teachers. Cambridge: Cambridge University Press.

4. Atkins J, Hailom B, Nuru M (1995) Skills Development Methodology; Part One: Addis Ababa: Addis Ababa University.

5. Baker J, Westrup H (2003) Essential Speaking Skills: A Handbook for English Language Teachers. London: Continuun International Publishing.

6. Haile B (1999) An Evaluation of the Implementation of Current ELT Syllabus for Grade Nine in Terms of the Communicative Language Teaching Methodology MA Thesis,
7. Gebru B (2008) Perception and Classroom Practice of Communicative Language Teaching by High School EFL teachers and Learners: The case of some Selected High Schools in Addis Ababa Addis Ababa: Addis Ababa University.

8. Haile B (1999) An Evaluation of the Implementation of Current ELT Syllabus for Grade Nine in Terms of the Communicative Language Teaching Methodology. MA Thesis.

9. Kebito B (2004) A Study on Analyses of Factors Affecting Students Speaking Skills: The Case of Grade Nine Students at Seyo Secondary School: Ambo: MA Thesis Unpublished.

10. Brown HD (1994) Teaching by Principles: An interactive approach to language pedagogy.

11. Brown HD (2007) Teaching by Principles: An interactive approach to language pedagogy. Prentice Hall Regents.

12. Cotter CH (2007) Speaking Well-Four Steps to Improve Your ESL EFL Students Speaking Ability.

13. Crystal D (2003) A Dictionary of Linguistics and Phonetics.

14. Ellis R (2003) Task-Based Language Learning and Teaching.

15. Mariam B (2006) The Communicative Language Teaching in Selected.

16. Scrinvener J (2005) Learning Teaching. UK: Macmillan Education.

17. Banteyirga $H$ (1982) "English Conditional Sentences: A Comparative Analysis of Structural and Communicative Approach in Teaching to Non-Native Speakers."

18. Harmer J (2001) The Practice of English Language Teaching. Harlow: Pearson Education Ltd.

19. Harmer J (2009) How to Teach English. London: Longman.

20. Hedge $T$ (2000) Teaching and Learning in the Language Classroom. Oxford Oxford University Press.

21. Hughes R (2002) Teaching and Researching Speaking. New York: Pearson Education.

22. Jack C (1992) Richards John Platt and Heidi Platt.

23. Johnson KE (1995) Understanding Communication in Second Language Classroom. Cambridge: Cambridge University Press.

24. Johnson DW, Johnson RT, Holubec EJ, Roy P (1984) Circles of Learning: Cooperation in the Classroom. Alexandria, VA: Association for Supervision and Curriculum Development.

25. Johnson DW, Johnson RT, Smith KA (1991) Cooperative learning: Increasing college faculty instructional productivity Washington, DC: School of Education and Human Development.

26. Kissock C, lyortsuun P (1982) Guide to Questioning: Classroom Procedures for Teachers. London: MacMillan Press Ltd.

27. Lakachew Mulat (2003) “Teachers' Attitude towards Communicative Language Teaching and Practical Problems in its Implementation." (Unpublished M.A. Thesis). Addis Ababa: Addis Ababa University.

28. Lindsay C, Knight P (2006) Learning and Teaching English, A Course for Teachers. Oxford: Oxford University Press.

29. Littlewood W (1981) 'Communicative Language Teaching: An Introduction', Cambridge: CUP.

30. Littlewood W (1999). Communicate Language Teaching. Cambridge: Cambridge University Press.

31. Long M (1996) Input, Interaction, and Second Language Acquisition. Unpublished doctoral dissertation. Los Angeles: University of California.

32. Luk JCM, Lin AMY (2007) Classroom Interactions as Cross-Cultural Encounters. Native speakers in EFL classrooms. Mahwah, New Jersey, London: Lawrence Erlbaum Associates, Publishers.

33. Mackey A (2007) The Conversational Interaction in Second Language Acquisition. Oxford: Oxford University Press.

34. Naimat G (2011) Influence of Teacher Students Interaction on EFL Reading Comprehension. European Journal of Social Sciences 23(4): 672-687.

35. Nazara S (2010) Students' Perception on EFL Speaking Skill Development. 
Citation: Adaba HW (2017) Exploring the Practice of Teacher-Student Classroom Interaction in EFL to Develop the Learners' Speaking Skills in Tullu Sangota Primary School Grade Eight Students in Focus. Arts Social Sci J 8: 295. doi: 10.4172/2151-6200.1000295

36. Norman K (1992) Thinking Voices. London: Hodder \& Stoughton.

37. Nugroho KY (2011) Interaction in English as a Foreign Language Classroom (A case of two state senior high schools in Semarang in the academic year 2009/2010).

38. Nunan D (1991) Language Teaching Methodology. London: Prentice Hall.

39. Nurmasitah S (2010) A Study of Classroom Interaction Characteristics in a Geography Class Conducted in English: The case at year ten of an immersion class in SMA N2 Semarang. Universitas Oiponegoro.

40. Richards JC, Rodgers TS (1986) Approaches and Methods in Language Teaching. Cambridge: Cambridge University Press.

41. Richards JC (2006) Developing Classroom Speaking Activities: From theory to practice. Guidelines-Singapore-Periodical for classroom language teachers then magazine for language teachers 28: 1-3.

42. Richards JC, Lockhart C (1996) Reflective Teaching in Second Language Teaching Classrooms. Cambridge: Cambridge University Press.

43. Richards JC, Rodgers TS (2001) Approaches and Methods in Language Teaching (2ndedn), Cambridge: Cambridge University Press.
44. Rivers WM (1981) Teaching foreign language skills (2ndedn), Chicago: University of Chicago Press.

45. Rivers WM (1987) Interaction as the Key to Teaching Language for Communication. Cambridge: Cambridge University Press.

46. Scrivener (1994) The Teacher Development Series. Heinemann University Press.

47. Thapa CB, Lin AMY (2013) Interaction in English Language Classrooms to Enhance Students Language Learning.

48. Thornbury S (2005) How to Teach Speaking. New York: Longman.

49. Penny UR (2000) A course in Language Teaching: Practice and Theory. Cambridge: Cambridge University Press.

50. Walsh M (2002) Teacher-Student Interaction and Language Learning. Annual Review of Applied Linguistics 22: 186-203.

51. Debebe $Y$ (2007) English Teachers Perception and Practice of Communicative Second Cycle Primary Schools in East Shoa Zone. 